\title{
Communication
}

\section{Exposure to SARS-CoV-2 in Aerosolized Wastewater: Toilet Flushing, Wastewater Treatment, and Sprinkler Irrigation}

\author{
Muhammad Usman ${ }^{1, *(D)}$, Muhammad Farooq ${ }^{2}\left(\mathbb{D}\right.$, Muhammad Farooq $^{3}$ (D) and Ioannis Anastopoulos $4, *(\mathbb{D})$ \\ 1 PEIE Research Chair for the Development of Industrial Estates and Free Zones, Center for Environmental \\ Studies and Research, Sultan Qaboos University, Muscat Al-Khoud 123, Oman \\ 2 Department of Clinical Sciences, College of Veterinary and Animal Sciences, Jhang, University of Veterinary \\ and Animal Sciences, Lahore 531, Pakistan; muhammad.farooq@uvas.edu.pk \\ 3 Department of Plant Sciences, Sultan Qaboos University, Muscat Al-Khoud 123, Oman; farooqcp@squ.edu.om \\ 4 Department of Electronics Engineering, School of Engineering, Hellenic Mediterranean University, \\ 73100 Chania, Crete, Greece \\ * Correspondence: muhammad.usman@squ.edu.om (M.U.); anastopoulos_ioannis@windowslive.com (I.A.)
}

Citation: Usman, M.; Farooq, M.;

Farooq, M.; Anastopoulos, I.

Exposure to SARS-CoV-2 in Aerosolized Wastewater: Toilet Flushing, Wastewater Treatment, and Sprinkler Irrigation. Water 2021, 13, 436. https://doi.org/10.3390/ w13040436

Academic Editor: Pankaj Kumar Received: 25 December 2020

Accepted: 5 February 2021

Published: 8 February 2021

Publisher's Note: MDPI stays neutral with regard to jurisdictional claims in published maps and institutional affiliations.

Copyright: (c) 2021 by the authors. Licensee MDPI, Basel, Switzerland. This article is an open access article distributed under the terms and conditions of the Creative Commons Attribution (CC BY) license (https:// creativecommons.org/licenses/by/ $4.0 /)$.

\begin{abstract}
The existence of SARS-CoV-2, the etiologic agent of coronavirus disease 2019 (COVID-19), in wastewater raises the opportunity of tracking wastewater for epidemiological monitoring of this disease. However, the existence of this virus in wastewater has raised health concerns regarding the fecal-oral transmission of COVID-19. This short review is intended to highlight the potential implications of aerosolized wastewater in transmitting this virus. As aerosolized SARS-CoV-2 could offer a more direct respiratory pathway for human exposure, the transmission of this virus remains a significant possibility in the prominent wastewater-associated bioaerosols formed during toilet flushing, wastewater treatment, and sprinkler irrigation. Implementing wastewater disinfection, exercising precautions, and raising public awareness would be essential. Additional research is needed to evaluate the survival, fate, and dissemination of SARS-CoV-2 in wastewater and the environment and rapid characterization of aerosols and their risk assessment.
\end{abstract}

Keywords: SARS-CoV-2; COVID-19; bioaerosol; aerosolized wastewater; environmental transmission; agriculture

\section{Introduction}

Recent research has demonstrated that people with coronavirus disease 2019 (COVID19), even those who do not develop symptoms, discharge its etiologic virus, severe acute respiratory syndrome coronavirus 2 (SARS-CoV-2), through their excrement [1]. The presence of SARS-CoV-2 RNA in sewage raises the possibility of analyzing wastewater for the epidemiological monitoring of COVID-19 [2]. Therefore, researchers in many countries are tracking SARS-CoV-2 in wastewater as a complementary approach to monitor the spread of COVID-19 [1].

The widespread existence of SARS-CoV-2 throughout wastewater systems could have important implications in the environmental transmission of COVID-19 [2-4]. Potential health concerns due to direct waterborne exposure to this virus in wastewater are well documented [5-7]. However, the aerosolized pathway must also be considered in this context as it could offer a more direct respiratory pathway for human exposure to SARS-CoV-2. Aerosolized viruses are often produced locally in buildings and on a larger scale during wastewater treatment or irrigation [8,9]. This short review is intended to highlight the potential implications of aerosolized SARS-CoV-2 generated from the top three wastewaterassociated sources of aerosol: toilet flushing, wastewater treatment, and sprinkler irrigation. Consistent with WHO, and the literature, here the term aerosol is referred for the small breathable particles of $<10 \mu \mathrm{m}\left(\mathrm{PM}_{10}\right)$ that can remain airborne with the capability of shortand long-range transport [10]. 
Inhalation of respiratory droplets/aerosols and/or interactions with contaminated surfaces are the main transmission routes of SARS-CoV-2, which is a highly contagious virus [11]. According to WHO (2020), airborne transmission of this virus is possible during aerosol-generating medical events. However, as reported in its scientific brief of 9 July, 2020, WHO is also evaluating the possibility of SARS-CoV-2 spread through aerosols in the absence of aerosol-producing processes [11]. Experimental studies involving aerosols of infectious samples found that SARS-CoV-2 can remain viable for up to several hours [12,13]. Moreover, aerosols are likely to contribute to longer-range transport and potential infection from the pathogens [10]. Therefore, it is critical to assess the potential of the aerosolized pathway where the probability of direct respiratory exposure to SARS-CoV2 is substantially higher. In this context, SARS-CoV-2 in aerosolized wastewater becomes an important scenario in its exposure pathways that should not be ruled out.

\section{Exposure to SARS-CoV-2 in Aerosolized Wastewater}

Although there is currently no proof of wastewater-related exposure to SARS-CoV-2, the contribution of aerosolized wastewater as a transmission route was recognized during the SARS epidemic of 2003 [14]. Respiration of virus-laden aerosols, created through the defective plumbing and sewage system, was recognized as a potential transmission route within a housing complex in Hong Kong where 187 people were infected [14]. Therefore, the transmission of this virus in aerosolized wastewater remains a significant possibility in the following scenarios: toilet flushing, wastewater treatment, and sprinkler irrigation (Figure 1). These scenarios are briefly described in the following sections.
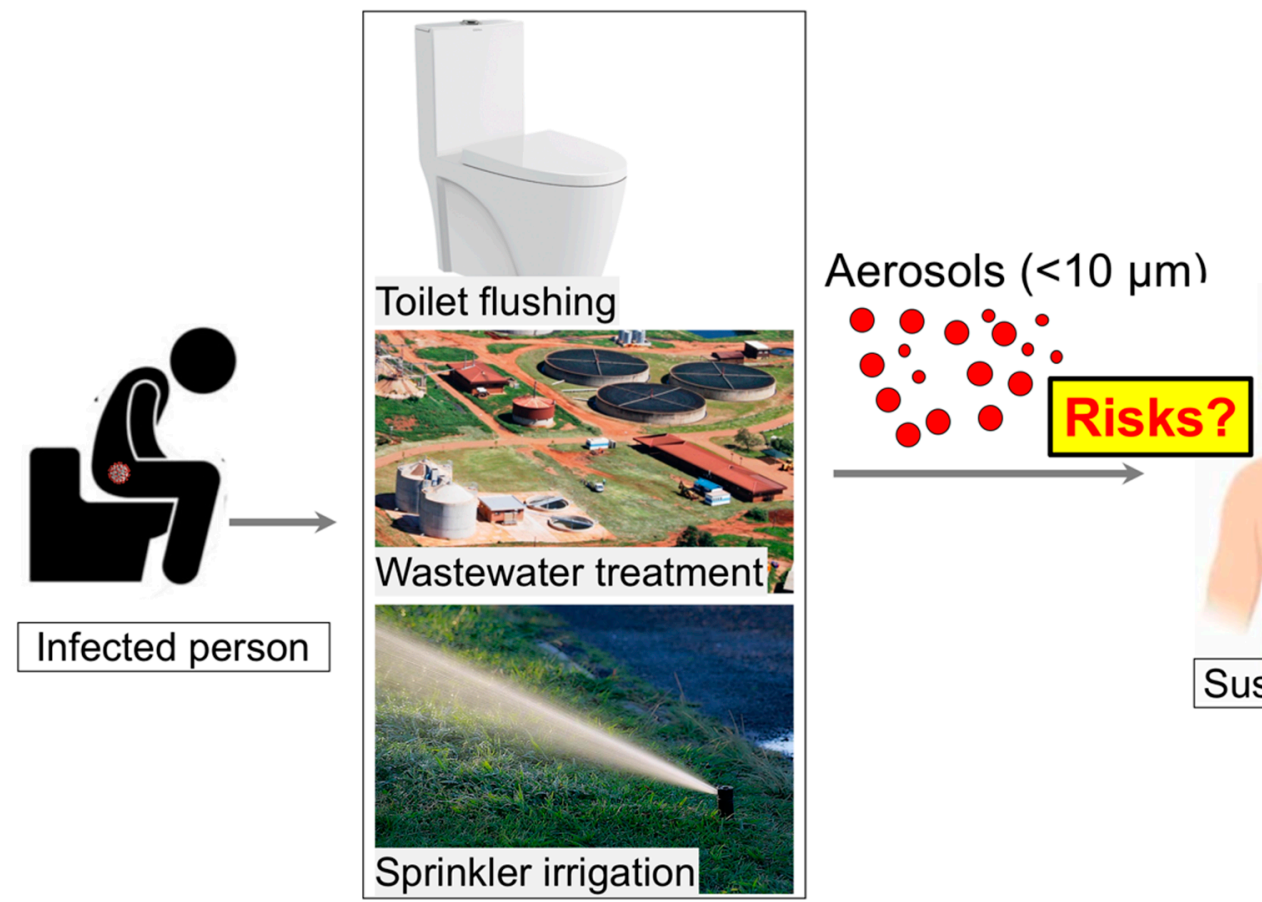

Figure 1. Overview of potential dissemination of SARS-CoV-2 (severe acute respiratory syndrome coronavirus 2) via aerosolized wastewater.

\subsection{Bioaerosol Generation by Toilet Flushing}

The toilet flushing creates a great deal of turbulence that generates bioaerosols containing pathogenic microorganisms [8]. For example, Wilson et al. [15] reported that toilet flushing increased the concentration of pathogens such as Clostridioides difficile in hospital air. Moreover, 95\% of these droplets were small enough $(<2 \mu \mathrm{m}$ diameter and $>99 \%$ $<5 \mu \mathrm{m})$ to present an airborne infection concern [16,17]. A full-scale pilot experiment on a two-story wastewater plumbing system using Pseudomonas putida (as a model pathogen 
being flushed into the system) revealed that pathogens can be aerosolized and transmitted between rooms [18]. Droplet fallout contaminated the surfaces within the system and rooms. Recently, Li et al. [19] used computational fluid dynamics to model fluid flows to estimate how far aerosol particles may transport due to toilet flushing. The simulations show a substantial upward transport of virus particles, $40-60 \%$ of which rise above the toilet seat and may reach to a height of $106.5 \mathrm{~cm}$ from the ground. Moreover, these particles remain suspended in the air more than a minute after the flush [19]. An analysis in two hospitals from Wuhan, China revealed that the concentration of SARS-CoV-2 RNA was high in patient toilets, while it was very low in aerosols in ventilated patient rooms and isolation wards [20]. In a hospital for COVID-19 patients, Ding et al. [21] marked toilets as the high-risk area where most of the identified SARS-CoV-2 RNA in the hospital emerged from the fecal-derived aerosols. Thus, bioaerosols generated by toilet flushing could potentially contribute to the environmental transmission of SARS-CoV-2. Though there does not exist any specific research on the toilet-associated generation of infectious bioaerosols containing SARS-CoV-2, it would be judicious to use precautions to prevent this transmission route [9]. Closing the lid on the toilet before flushing and cleaning the toilet seat before using it has been recommended [17,19]. Environmental disinfection of toilet areas should be imposed in healthcare facilities and public toilets [20]. Toilets are generally indoor, having limited potential for aerosolized virus dilution as compared with the outdoor settings (wastewater treatment facilities and sprinkler irrigation systems). It has also been recommended to ensure sufficient and effective ventilation, possibly enhanced by air filtration and disinfection [22]. In addition, modification in toilet designs should also be considered [19]. Raising public awareness is crucial to impede the toilet-associated transmission of SARS-CoV-2.

\subsection{Bioaerosol Produced during Wastewater Treatment}

Wastewater contains a high number of pathogens such as viruses, bacteria, and parasites. Processes involved in wastewater treatment may lead to the aerosolization of these pathogens $[23,24]$. Therefore, bioaerosols generated at cooling towers and wastewater treatment plants (WWTPs) have been widely considered as a potential health hazard for sewage workers and nearby communities [24,25]. For example, Masclaux et al. [23] found adenovirus RNA in $100 \%$ of summer air samples of WWTP and $97 \%$ of winter samples. They detected norovirus in only 3 of the 123 air samples, but no sample contained the hepatitis E virus. Courault et al. [25] detected hepatitis E virus and norovirus RNA in the aerosol produced from active sludge basins of WWTPs and in that of plots irrigated with the treated water. Indeed, risks of SARS-CoV-2 aerosolization can be particularly high in uncovered aerobic wastewater treatment facilities like an aerobic tank [26] and activated sludge process [23]. The potential for the coronaviruses to become aerosolized increases with the transport in water [27], particularly during the pumping of wastewater, during its discharge and subsequent flow through the drainage network [28]. Substantial load of SARS-CoV-2 arriving at WWTPs should raise concerns for its aerosolization and ultimate implications in public health. Due to the significant concentrations of SARS-CoV-2 RNA in wastewater, WWTPs are gaining attention for early tracking and removal of this virus [29]. The viral loads can be decreased in WWTPs by wastewater disinfection and filtration $[3,30]$. However, the effects of the disinfection process on the microbial community in wastewater, antimicrobial resistance, and associated environmental risks should also be considered [31]. Safety practices should be particularly ensured to protect the health of sanitation workers.

\subsection{Bioaerosol Produced during Irrigation}

The use of sprinkler/spray irrigation is prevalent in many countries to apply treated wastewater in urban green spaces and agricultural soils. Sprinkler irrigation can potentially aerosolize the pathogens if present in the wastewater [32]. It can provide a respiratory route for exposure to the irrigators and community members in the vicinity [25,33]. In addition to the irrigation method, viruses and other pathogens transported to the soil by irrigation 
water can also be aerosolized later during windy spells [34]. Indeed, 1-15\% of viruses transported to the soil with irrigation water were aerosolized, of which $11-89 \%$ were aerosolized within the first $30 \mathrm{~min}$ [34]. Risk assessment of airborne enteric viruses, released from wastewater used for irrigation in France, revealed that an increase in wind speed and a decrease in distance from the pathogen source can significantly increase the probability of infection [25]. Similarly, pathogens can be aerosolized in wastewater canals [35]. This can pose disproportionate risks to developing communities having poor sewage infrastructure. As reported in the 2017 World Water Development Report of the United Nations, $80 \%$ of wastewater worldwide ( $>95 \%$ in some developing countries) is discharged into the environment without suitable treatment.

\section{Concluding Remarks and Perspectives}

The COVID-19 patients discharge infectious SARS-CoV-2 virus in their feces [36,37], highlighting the potential of transmission through fecal-oral route. However, the existing data on SARS-CoV-2 detection in wastewater were obtained by PCR and not by cell infection. Therefore, there exists a clear knowledge gap regarding the detection of infectious SARS-CoV-2 in wastewater. Moreover, further research is needed to assess the survival of the infectious viruses in wastewater. The evidence from surrogate corona viruses such as murine hepatitis virus (MHV) and transmissible gastroenteritis virus (TGEV) showed that it takes at least 10 days for $99 \%$ inactivation of these viruses in lake water [38]. That may further highlight the transmission potential of corona viruses such as SARS-COV2 through wastewater.

Though there is no concrete evidence for the spread of SARS-CoV-2 through aerosolized wastewater, its role in the environmental transmission of COVID-19 cannot be ruled out. Protection of workers in these fields needs immediate attention. For that, authorities should ensure that workers, particularly those facing greater exposure risk, have access to appropriate protective equipment, adequate training in infection control, high testing rates, and paid sick leave. The situation is particularly critical in developing communities due to poor sewage infrastructures and their lack of access to adequate water and hygiene facilities. Substantial viral load within aerosolized wastewater calls for effective disinfection of wastewater to prevent the formation of pathogen-laden aerosols. Expertise in wastewater science and technology would be required, whereas transition to the aerosol phase calls for treatment according to aerosol standards. Research is also needed for the rapid characterization of aerosols, measurement of SARS-CoV-2 in wastewater aerosols, and their risk assessment.

Author Contributions: M.U.: Conceptualization, Writing—Review and Editing, M.F. (1): WritingReview and Editing, M.F. (2): Writing—Review and Editing, I.A.: Writing—Review and Editing. All authors have read and agreed to the published version of the manuscript.

Funding: This research was funded by a research grant to M. Usman from Madayn-Public Establishment for Industrial Estates, Oman (CHAIR/DVC/MADAYN/20/02).

Institutional Review Board Statement: Not applicable.

Informed Consent Statement: Not applicable.

Data Availability Statement: No new data were created or analyzed in this study. Data sharing is not applicable to this article.

Conflicts of Interest: The authors declare no conflict of interest.

\section{References}

1. Bivins, A.; North, D.; Ahmad, A.; Ahmed, W.; Alm, E.; Been, F.; Bhattacharya, P.; Bijlsma, L.; Boehm, A.B.; Brown, J.; et al. Wastewater-Based Epidemiology: Global Collaborative to Maximize Contributions in the Fight Against COVID-19. Environ. Sci. Technol. 2020, 54, 7754-7757. [CrossRef] [PubMed]

2. Lodder, W.; de Roda Husman, A.M. SARS-CoV-2 in wastewater: Potential health risk, but also data source. Lancet Gastroenterol. Hepatol. 2020, 5, 533-534. [CrossRef] 
3. Usman, M.; Farooq, M.; Hanna, K. Existence of SARS-CoV-2 in Wastewater: Implications for Its Environmental Transmission in Developing Communities. Environ. Sci. Technol. 2020, 54, 7758-7759. [CrossRef]

4. Franklin, A.B.; Bevins, S.N. Spillover of SARS-CoV-2 into novel wild hosts in North America: A conceptual model for perpetuation of the pathogen. Sci. Total Environ. 2020, 733, 139358. [CrossRef]

5. Collivignarelli, M.C.; Collivignarelli, C.; Carnevale Miino, M.; Abbà, A.; Pedrazzani, R.; Bertanza, G. SARS-CoV-2 in sewer systems and connected facilities. Process Saf. Environ. Prot. 2020, 143, 196-203. [CrossRef]

6. SanJuan-Reyes, S.; Gómez-Oliván, L.M.; Islas-Flores, H. COVID-19 in the environment. Chemosphere 2021, 263, 127973. [CrossRef]

7. Bogler, A.; Packman, A.; Furman, A.; Gross, A.; Kushmaro, A.; Ronen, A.; Dagot, C.; Hill, C.; Vaizel-Ohayon, D.; Morgenroth, E.; et al. Rethinking wastewater risks and monitoring in light of the COVID-19 pandemic. Nat. Sustain. 2020, 3, 981-990. [CrossRef]

8. Knowlton, S.D.; Boles, C.L.; Perencevich, E.N.; Diekema, D.J.; Nonnenmann, M.W.; Program, C.D.C.E. Bioaerosol concentrations generated from toilet flushing in a hospital-based patient care setting. Antimicrob. Resist. Infect. Control 2018, 7, 16. [CrossRef] [PubMed]

9. Gormley, M.; Aspray, T.J.; Kelly, D.A. COVID-19: Mitigating transmission via wastewater plumbing systems. Lancet Glob. Health 2020, 8, e643. [CrossRef]

10. Anderson, E.L.; Turnham, P.; Griffin, J.R.; Clarke, C.C. Consideration of the Aerosol Transmission for COVID-19 and Public Health. Risk Anal. 2020, 40, 902-907. [CrossRef]

11. WHO. Transmission of SARS-CoV-2: Implications for Infection Prevention Precautions. 2020. Available online: https://www.who. $\mathrm{int} /$ news-room/commentaries/detail/transmission-of-sars-cov-2-implications-for-infection-prevention-precautions (accessed on 15 December 2020).

12. Fears, A.; Klimstra, W.; Duprex, P.; Hartman, A.; Weaver, S.; Plante, K.; Mirchandani, D.; Plante, J.A.; Aguilar, P.; Fernández, D.; et al. Persistence of Severe Acute Respiratory Syndrome Coronavirus 2 in Aerosol Suspensions. Emerg. Infect. Dis. 2020, 26. [CrossRef] [PubMed]

13. Van Doremalen, N.; Bushmaker, T.; Morris, D.H.; Holbrook, M.G.; Gamble, A.; Williamson, B.N.; Tamin, A.; Harcourt, J.L.; Thornburg, N.J.; Gerber, S.I.; et al. Aerosol and Surface Stability of SARS-CoV-2 as Compared with SARS-CoV-1. N. Engl. J. Med. 2020, 382, 1564-1567. [CrossRef] [PubMed]

14. Yu, I.T.S.; Li, Y.; Wong, T.W.; Tam, W.; Chan, A.T.; Lee, J.H.W.; Leung, D.Y.C.; Ho, T. Evidence of Airborne Transmission of the Severe Acute Respiratory Syndrome Virus. N. Engl. J. Med. 2004, 350, 1731-1739. [CrossRef]

15. Wilson, G.M.; Jackson, V.B.; Boyken, L.D.; Schweizer, M.L.; Diekema, D.J.; Petersen, C.A.; Breheny, P.J.; Nonnenmann, M.W.; Perencevich, E.N. Bioaerosols generated from toilet flushing in rooms of patients with Clostridioides difficile infection. Infect. Control Hosp. Epidemiol. 2020, 41, 517-521. [CrossRef] [PubMed]

16. Johnson, D.; Lynch, R.; Marshall, C.; Mead, K.; Hirst, D. Aerosol Generation by Modern Flush Toilets. Aerosol Sci. Technol. 2013, 47, 1047-1057. [CrossRef] [PubMed]

17. McDermott, C.V.; Alicic, R.Z.; Harden, N.; Cox, E.J.; Scanlan, J.M. Put a lid on it: Are faecal bio-aerosols a route of transmission for SARS-CoV-2? J. Hosp. Infect. 2020, 105, 397-398. [CrossRef]

18. Gormley, M.; Aspray, T.J.; Kelly, D.A.; Rodriguez-Gil, C. Pathogen cross-transmission via building sanitary plumbing systems in a full scale pilot test-rig. PLoS ONE 2017, 12, e0171556. [CrossRef]

19. Li, Y.-Y.; Wang, J.-X.; Chen, X. Can a toilet promote virus transmission? From a fluid dynamics perspective. Phys. Fluids 2020, 32, 065107. [CrossRef]

20. Liu, Y.; Ning, Z.; Chen, Y.; Guo, M.; Liu, Y.; Gali, N.K.; Sun, L.; Duan, Y.; Cai, J.; Westerdahl, D.; et al. Aerodynamic analysis of SARS-CoV-2 in two Wuhan hospitals. Nature 2020, 582, 557-560. [CrossRef]

21. Ding, Z.; Qian, H.; Xu, B.; Huang, Y.; Miao, T.; Yen, H.-L.; Xiao, S.; Cui, L.; Wu, X.; Shao, W.; et al. Toilets dominate environmental detection of severe acute respiratory syndrome coronavirus 2 in a hospital. Sci. Total Environ. 2021, 753, 141710. [CrossRef]

22. Tang, J.W.; Bahnfleth, W.P.; Bluyssen, P.M.; Buonanno, G.; Jimenez, J.L.; Kurnitski, J.; Li, Y.; Miller, S.; Sekhar, C.; Morawska, L.; et al. Dismantling myths on the airborne transmission of severe acute respiratory syndrome coronavirus (SARS-CoV-2). J. Hosp. Infect. 2021. [CrossRef] [PubMed]

23. Masclaux, F.G.; Hotz, P.; Gashi, D.; Savova-Bianchi, D.; Oppliger, A. Assessment of airborne virus contamination in wastewater treatment plants. Environ. Res. 2014, 133, 260-265. [CrossRef]

24. Tian, J.-H.; Yan, C.; Nasir, Z.A.; Alcega, S.G.; Tyrrel, S.; Coulon, F. Real time detection and characterisation of bioaerosol emissions from wastewater treatment plants. Sci. Total Environ. 2020, 721, 137629. [CrossRef]

25. Courault, D.; Albert, I.; Perelle, S.; Fraisse, A.; Renault, P.; Salemkour, A.; Amato, P. Assessment and risk modeling of airborne enteric viruses emitted from wastewater reused for irrigation. Sci. Total Environ. 2017, 592, 512-526. [CrossRef]

26. Han, Y.; Yang, K.; Yang, T.; Zhang, M.; Li, L. Bioaerosols emission and exposure risk of a wastewater treatment plant with A2O treatment process. Ecotoxicol. Environ. Saf. 2019, 169, 161-168. [CrossRef] [PubMed]

27. Casanova, L.; Rutala, W.A.; Weber, D.J.; Sobsey, M.D. Survival of surrogate coronaviruses in water. Water Res. 2009, 43, 1893-1898. [CrossRef] [PubMed]

28. Quilliam, R.S.; Weidmann, M.; Moresco, V.; Purshouse, H.; O’Hara, Z.; Oliver, D.M. COVID-19: The environmental implications of shedding SARS-CoV-2 in human faeces. Environ. Int. 2020, 140, 105790. [CrossRef] 
29. Lesimple, A.; Jasim, S.Y.; Johnson, D.J.; Hilal, N. The role of wastewater treatment plants as tools for SARS-CoV-2 early detection and removal. J. Water Process Eng. 2020, 38, 101544. [CrossRef]

30. Naddeo, V.; Liu, H. Editorial Perspectives: 2019 novel coronavirus (SARS-CoV-2): What is its fate in urban water cycle and how can the water research community respond? Environ. Sci. Water Res. Technol. 2020, 6, 1213-1216. [CrossRef]

31. Usman, M.; Farooq, M.; Hanna, K. Environmental side effects of the injudicious use of antimicrobials in the era of COVID-19. Sci. Total Environ. 2020, 745, 141053. [CrossRef]

32. Pepper, I.L.; Gerba, C.P. Risk of infection from Legionella associated with spray irrigation of reclaimed water. Water Res. 2018, 139, 101-107. [CrossRef]

33. Hamilton, K.A.; Hamilton, M.T.; Johnson, W.; Jjemba, P.; Bukhari, Z.; LeChevallier, M.; Haas, C.N. Health risks from exposure to Legionella in reclaimed water aerosols: Toilet flushing, spray irrigation, and cooling towers. Water Res. 2018, 134, 261-279. [CrossRef]

34. Girardin, G.; Renault, P.; Bon, F.; Capowiez, L.; Chadoeuf, J.; Krawczyk, C.; Courault, D. Viruses carried to soil by irrigation can be aerosolized later during windy spells. Agron. Sustain. Dev. 2016, 36, 59. [CrossRef]

35. Dickin, S.K.; Schuster-Wallace Corinne, J.; Qadir, M.; Pizzacalla, K. A Review of Health Risks and Pathways for Exposure to Wastewater Use in Agriculture. Environ. Health Perspect. 2016, 124, 900-909. [CrossRef]

36. Wang, W.; Xu, Y.; Gao, R.; Lu, R.; Han, K.; Wu, G.; Tan, W. Detection of SARS-CoV-2 in Different Types of Clinical Specimens. JAMA 2020, 323, 1843-1844. [CrossRef] [PubMed]

37. Xiao, F.; Sun, J.; Xu, Y.; Li, F.; Huang, X.; Li, H.; Zhao, J.; Huang, J.; Zhao, J. Infectious SARS-CoV-2 in Feces of Patient with Severe COVID-19. Emerg. Infect. Dis. J. 2020, 26, 1920. [CrossRef] [PubMed]

38. Tran, H.N.; Le, G.T.; Nguyen, D.T.; Juang, R.-S.; Rinklebe, J.; Bhatnagar, A.; Lima, E.C.; Iqbal, H.M.N.; Sarmah, A.K.; Chao, H.-P. SARS-CoV-2 coronavirus in water and wastewater: A critical review about presence and concern. Environ. Res. 2021, $193,110265$. [CrossRef] 